\title{
Influence of Perceived University Support, Perceived Effective Entrepreneurship Education, Perceived Creativity Disposition, Entrepreneurial Passion for Inventing and Founding on Entrepreneurial Intention
}

\author{
Abdullahi Nasiru* \\ Ooi Yeng Keat \\ Muhammad Awais Bhatti \\ Othman Yeop Abdullah Graduate School of Business, Universiti Utara Malaysia, 06010 Sintok, Kedah, Malaysia \\ *elnasir@gmail.com
}

\section{Doi:10.5901/mjss.2015.v6n3p88}

\begin{abstract}
We modeled the relationship between entrepreneurship intention and five other variables, including two as formative secondorder constructs. We therefore, employed the use of SmartPLS (2.0) to analyze the influence of perceived effective entrepreneurship education, perceived University support, perceived creativity disposition, entrepreneurial passion for inventing and entrepreneurial passion for founding on entrepreneurial intention. The PLS was readily employed in this study for its ability to estimate a formative measured variable. The first-order reflective and second-order formative variables model parameters were estimated by employing the two-stage approach. Using a sample of 595 students from three Federal Universities in Northern Nigeria, the study found a significant positive relationship between perception of University support, perceived creativity disposition, entrepreneurial passion for inventing, entrepreneurial passion for founding and entrepreneurial intention. However, an unexpectedly significant negative relationship was found between perceived effective entrepreneurship education and entrepreneurial intention. Implications for the findings are provided.
\end{abstract}

Keywords: Entrepreneurial intention, University support, effective entrepreneurship education, creativity disposition, entrepreneurial passion.

\section{Introduction}

Entrepreneurship contributes significantly to any country's economy by spurring job creation, innovativeness and creativity, high employment, positive social development as well as economic growth (Acs \& Audretsch, 2005; Rowley, Baregheh, \& Sambrook, 2011; Schiavone, 2011; Shane \& Venkataraman, 2000). Accordingly, entrepreneurial attitudes, entrepreneurial intentions (EI) and entrepreneurial actions must be appreciated to comprehend entrepreneurship (Krueger, 2007).

Entrepreneurial intentions (EI) is fundamental to comprehend the entrepreneurial procedure as it precede any attempt in entrepreneurial behaviour (Arendt \& Brettel, 2010; Krueger \& Carsrud, 1993; Lin, Lin, \& Lin, 2010) and it is the most excellent predictor of entrepreneurial behaviour (Ajzen, 1991; Fitzsimmons \& Douglas, 2011; Shapero \& Sokol, 1982). Hence, appreciating the factors that influence El is useful to explain entrepreneurial behaviour (Shane \& Venkataraman, 2000).

Scholars have recognised the importance of entrepreneurship education as it influences students' intention to become entrepreneurs (Autio, Keeley, Klofsten, \& Ulfstedt, 1997; Franke \& Lüthje, 2004; Packham, Jones, Miller, Pickernell, \& Thomas, 2010; Schwarz, Wdowiak, Almer-Jarz, \& Breitenecker, 2009; Souitaris, et al., 2007). It develops and enhances managerial skills necessary for business success (Wilson, Kickul, \& Marlino, 2007). Hence, the calls for more researches about its link with outcome variables, given also that the value and effect of entrepreneurship education is yet to be established (Albornoz \& Rocco, 2013; Peterman \& Kennedy, 2003)

Passion also occupies a central place in entrepreneurship (Cardon, Zietsma, Saparito, Matherne, \& Davis, 2005). It encourages creativeness and the realization of novel important information necessary to recognise and invest in successful business prospects (Baron, 2008; Sundararajan \& Peters, 2007). Most studies on passion (Baum \& Locke, 2004; Chen, et al., 2009) however, focuses on individual entrepreneurial passion in relation to outcomes related to organisations and other outcomes that are behavioural (Murnieks, et al., 2011) or otherwise without direct emphasis on 
entrepreneurial intentions. This research therefore took a step further to examine the direct relationship between entrepreneurial passion and entrepreneurial intentions.

Creativity and innovation are important personality traits for entrepreneurship (Luca \& Cazan, 2011; Ward, 2005). Literature indicates that creative individual will most probably engage in entrepreneurial behaviour (Ward, 2004) Consequently, investigating creative dispositions and entrepreneurial intentions of students is necessary believing that, students' entrepreneurial intentions depends to an extent on how they perceived themselves as creative. Moreover, several studies have supported self-assessment of creativity disposition (Batey \& Furnham, 2008).

Furthermore, some studies considered the effect of both personal and contextual/environmental factors including university environment on intention, but the role of university support in promoting intention need to be established (Liñán, Urbano, \& Guerrero, 2011b). This research is conducted with the aim to improve on the understanding of the determinants of entrepreneurial intention among students towards creating their own ventures after graduation.

\section{Literature Review}

The review of the literature indicates that entrepreneurship kick-starts with opportunity identification and the process is undoubtedly an intentional process (Wang, et al., 2011). El is the deliberate state of mind that precedes action and push thought in the direction of establishing business as a target (Bird, 1989; Shane \& Venkataraman, 2000). Entrepreneurial intention can also be use to predict involvement among students in entrepreneurship and explain why students decide to venture into business (Ariff, et al., 2010). Understanding the real factors responsible for shaping intention of students to begin a new venture is fundamental for building the programmes and policies aim at promoting entrepreneurial behaviour (Bakotić \& Kružić, 2010; Lüthje \& Franke, 2003).

Generally, researchers describe entrepreneurial intention in terms of three common factors influencing it; individual attitude to behaviour, perceived social norms, and individual self-efficacy (Krueger Jr, et al., 2000; Liñán, et al., 2005). Subsequently, A number of studies (Franke \& Lüthje, 2004; Rodrigues, et al., 2008) investigated to find the most important variables that influence graduates to initiate a business venture. According to Lee \& Wong (2004) the intention to exhibit entrepreneurial behaviours could be influenced by some cognitive factors like; needs, values, wants, habits, and beliefs. The significance of cognitive variables in understanding the individual decision process has been pointed out by researchers like Baron (2004) and Shaver \& Scott (1991). Therefore, the cognitive perspective makes understanding the difficult process of entrepreneurship easier.

In prior study, personal and environment determinants of entrepreneurial intention including attitudes toward entrepreneurship, personality traits and social environment have been given much concern (Davidsson, 1995; Franke \& Lüthje, 2004; Robinson \& Haynes, 1991; Segal, et al., 2005). Even though, there are inconsistencies across studies, there is a general link between personality factors and entrepreneurial intention, but personality is exhibited within certain domain of demographical, cultural, economical, social, political and technological factors (Hisrich, 1990). For this reason, past literature categorize individual domains and contextual variables as the two important categories necessary for shaping El (Bird, 1988).

Furthermore, the ability to think creatively or the perception that one poses creative ability could explain why some people would choose to be or not to be entrepreneurs. Hence creative individuals are more expected to engage in entrepreneurship behaviour (Ward, 2004). Moreover, several studies have supported self-assessment of creativity disposition (Batey \& Furnham, 2008). Therefore, people should be allowed to make effort to judge themselves as capable of generating new and valuable ideas necessary to succeed as entrepreneurs (Darini, et al., 2011). This study thus, investigated further, the influence of individual students' creativity disposition on entrepreneurial intentions, which has hardly been considered in intention based models (Hamidi, et al., 2008).

Another factor of concern is entrepreneurship education, which its definitions connotes effectiveness of entrepreneurship education that provides individuals with practical sense of business, building self-confidence and developing skill for a successful business venture (Wilson, et al., 2007). The relative expensiveness of running a successful and effective entrepreneurship education program (Charney, et al., 2000) exposes the need therefore, of faculties and universities to intervene in their various roles to enhance the achievement of this goal of initiating and encouraging business start-up by young graduates. Hence, the challenge for the developing world is to help develop graduate entrepreneurs and provide suitable and supportive environments that can contribute to the growth of entrepreneurship (Nabi \& Liñán, 2011). University here becomes a focal point as the first initiator to consider. While also in developing countries the research on enterprise/entrepreneurship education and entrepreneurial intentions is highly under research (Nabi \& Liñán, 2011). Hence, this study determined the influence of Perceived effective entrepreneurship education on entrepreneurial intention of university students. 
Passion is yet another fundamental factor in entrepreneurship (Bird, 1988; Cardon, et al., 2013) and has affective, cognitive, and behavioural components (Chen, et al., 2009), which influence people behaviour (Cardon, et al., 2009b; Murnieks, et al., 2011). Consequently, if passion is quite integral to successful entrepreneurship activities, then, it is only logical that this must be present or build prior to setting up of ventures. Also, most studies on passion (Baum \& Locke, 2004; Chen, et al., 2009) focus on individual entrepreneurial passion in relation to outcomes that affect organisations and other outcomes that are behavioural (Murnieks, et al., 2011) or otherwise without direct emphasis on entrepreneurial intentions. Even, studies that considered passion with intention, does so indirectly by observing the impact of passion as a moderator to other antecedent factors (De Clercq, et al., 2011) or as antecedent to other variables that explain its impact (Murnieks, et al., 2011; Vallerand, et al., 2007). This study therefore went further to investigate the direct relationship between entrepreneurial passion and entrepreneurial intentions. Consequently, we develope the following Hypotheses:

Hypothesis 1. Entrepreneurial passion for founding has a positive influence on entrepreneurial intention.

Hypothesis 2. Entrepreneurial passion for inventing has a positive influence on entrepreneurial intention.

Hypothesis 3. Perceived creativity disposition has a positive influence on entrepreneurial intention.

Hypothesis 4. Perceived effective entrepreneurship education has a positive influence on entrepreneurial intention.

Hypothesis 5. Perception of university support has a positive influence on entrepreneurial intention.

\section{Method}

\subsection{Participants and procedures}

Conducting a survey research, this study sampled 595 students from three federal universities in the North-western Nigeria. Based on a stratified random sampling, students were drawn in proportionate to the total number of students in their respective strata and subsequently random sampling was employed to arrive at the sampled population from various departments of faculties. The administration and collection process of the questionnaire involved research assistants with the help of entrepreneurship coordinating teams of the various universities, whom ensured efficient and effective data collection.

\subsection{Instrumentation and Measurement of Variables}

The summary of measures of variables adopted is presented in table 1.

Table 1: Summary of measures of variables

\begin{tabular}{|l|c|l|}
\hline Variables & Items & Sources \\
\hline Entrepreneurial Intentions & 6 & Linãn and Chen (2009) \\
\hline Perceive effective Entrepreneurial Education & 5 & Souitaris et al. (2007) \\
\hline Entrepreneurial Passion Domain: & 5 & \\
Entrepreneurial Passion for Inventing & 4 & Cardon et al., (2013) \\
Entrepreneurial Passion for Founding & 8 & Zhou and George (2001) \\
\hline Perceive Creativity Disposition & 14 & Autio et al. (1997) \& Keat (2011) \\
\hline University Support & &
\end{tabular}

Note: All variables were measured on a 7-point Likert scale.

\subsection{Analysis Technique}

Smart Partial Least Square (SmartPLS) was employed to run multivariate test and analyses and also for testing hypothesis formulated for the study. The PLS approach was employed for its ability to analyze the relationship between the latent variables and their measures, modeled in a reflective or formative ways as well as hybrid formative and reflective constructs (Hair et al., 2014). The model for this study involves a formative second order variable. We used the SmartPLS 2.0 (Ringle et al., 2005) to compute the path model and estimated the parameters based on path weighting scheme (Henseler et al., 2012). We first assessed the measurement models and then evaluated the structural model and reported our results in that order. 


\section{Results}

The study used a two-stage approach in the analysis because the constructs of entrepreneurial passion for inventing (EPI) and entrepreneurial passion for founding (EPF) consisted of formative measures. In the first stage we assessed the measurement model of the first-order constructs with the presence of the second-order constructs and in the second stage we considered the structural relationships using factor scores for all the variables in our model (Ringle et al., 2012; Wilson, 2010). Figure 1 shows the structural model.

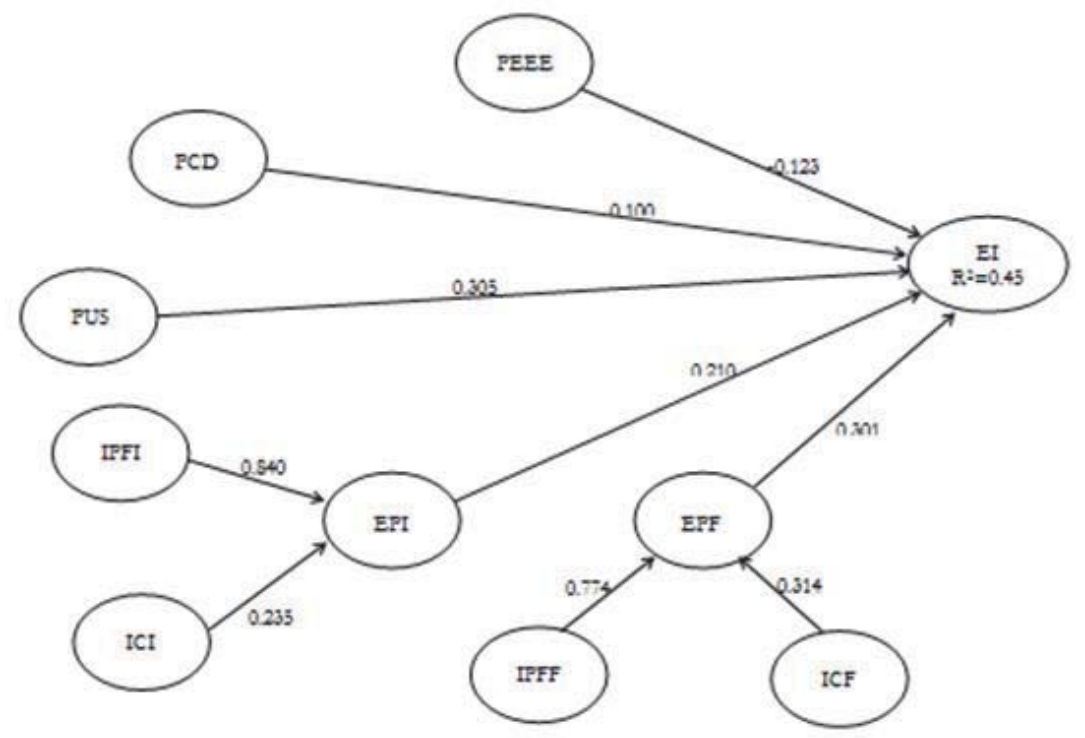

Figure 1: Structural model

Table 2 shows the descriptive statistics for the research constructs.

Table 2: Descriptive Statistics

\begin{tabular}{lcc}
\hline Construct & Mean & Std. Deviation \\
\hline Perceive Effective Entrepreneurship Education & 5.367 & 1.120 \\
Perceive Creativity Disposition & 5.187 & 1.075 \\
Entrepreneurial Passion for Inventing & 5.366 & 1.161 \\
Entrepreneurial Passion for Founding & 5.610 & 1.136 \\
Perception of University Support & 4.827 & .847 \\
Entrepreneurial Intention & 5.431 & 1.366 \\
\hline
\end{tabular}

\subsection{Measurement Model}

In evaluating the measurement model we examined the outer model (Hair et al., 2014) by assessing the relationship between the constructs and their indicators. As shown in Table 3, for the internal consistency reliability, the composite reliability ranged from .85 to .94 for the first-order constructs, exceeding the minimum requirement of .70 . The average variance extracted (AVE) for the measurement model is more than .57 for all constructs, exceeding the cutoff of .50 (Hair et al., 2012), hence meeting the convergent validity for all constructs. In Table 4, the AVEs are shown on the diagonal and the squared interconstruct correlations are off the diagonal. Following Fornell-Larcker (1998) in assessing discriminant validity table 4 demonstrated that all AVEs are higher than the squared interconstruct correlations, which has also satisfied the requirement for discriminant validity. To further assess the discriminant validity we examined the indicators cross loadings and all indicator loadings were higher than their respective cross loadings. This further confirms discriminant validity (Hair et al., 2014). The study hence, confirmed the reliability and validity of our constructs. 
Table 3: Item loading, internal consistency, and average variance extracted for the first-order constructs

\begin{tabular}{|c|c|c|c|c|}
\hline Construct & Indicators & Loadings & Composite Reliability & AVE \\
\hline \multirow[t]{5}{*}{ Entrepreneurial Intention } & El2 & .776 & \multirow[t]{5}{*}{.941} & \multirow[t]{5}{*}{.762} \\
\hline & $\mathrm{El} 3$ & .899 & & \\
\hline & El4 & .914 & & \\
\hline & El5 & .896 & & \\
\hline & El6 & .872 & & \\
\hline Identity Centrality for Founding & ICF & 1.000 & 1.000 & 1.000 \\
\hline Identity Centrality for Inventing & $\mathrm{ICl}$ & 1.000 & 1.000 & 1.000 \\
\hline \multirow[t]{3}{*}{ Intense Positive Feeling for Founding } & IPFF1 & .825 & \multirow[t]{3}{*}{.866} & \multirow[t]{3}{*}{.682} \\
\hline & IPFF2 & .852 & & \\
\hline & IPFF3 & .801 & & \\
\hline \multirow[t]{4}{*}{ Intense Positive Feeling for Inventing } & IPFI1 & .815 & \multirow[t]{4}{*}{.898} & \multirow[t]{4}{*}{.688} \\
\hline & IPFI2 & .835 & & \\
\hline & IPFI3 & .851 & & \\
\hline & IPFI4 & .816 & & \\
\hline \multirow[t]{7}{*}{ Perceive Creativity Disposition } & PCD2 & .742 & \multirow[t]{7}{*}{.904} & \multirow[t]{7}{*}{.574} \\
\hline & PCD3 & .747 & & \\
\hline & PCD4 & .748 & & \\
\hline & PCD5 & .740 & & \\
\hline & PCD6 & .801 & & \\
\hline & PCD7 & .802 & & \\
\hline & PCD8 & .720 & & \\
\hline \multirow[t]{5}{*}{ Perceive Effective Entrepreneurship Education } & PEEE1 & .824 & \multirow[t]{5}{*}{.887} & \multirow[t]{5}{*}{.611} \\
\hline & PEEE2 & .839 & & \\
\hline & PEEE3 & .784 & & \\
\hline & PEEE4 & .708 & & \\
\hline & PEEE5 & .745 & & \\
\hline \multirow[t]{4}{*}{ Perception of University Support } & PUS5 & .738 & \multirow[t]{4}{*}{.846} & \multirow[t]{4}{*}{.579} \\
\hline & PUS6 & .775 & & \\
\hline & PUS7 & .781 & & \\
\hline & PUS8 & .748 & & \\
\hline
\end{tabular}

Table 4: Square Root of AVE and correlations of latent variables for the first-order constructs

\begin{tabular}{|c|c|c|c|c|c|c|c|c|}
\hline & 1 & 2 & 3 & 4 & 5 & 6 & 7 & 8 \\
\hline 1) Entrepreneurial Intention & .873 & & & & & & & \\
\hline 2) Identity Centrality for Founding & .446 & Single Item & & & & & & \\
\hline 3) Identity Centrality for Inventing & .426 & .407 & Single Item & & & & & \\
\hline 4) Intense positive feelings for founding & .528 & .623 & .450 & .826 & & & & \\
\hline 5) Intense positive feelings for Inventing & .532 & .492 & .603 & .620 & .829 & & & \\
\hline 6) Perceive Creativity Disposition & .447 & .388 & .493 & .481 & .599 & .758 & & \\
\hline 7) Perceive Effective Entrepreneurship Education & .261 & .347 & .384 & .398 & .528 & .491 & .782 & \\
\hline 8) Perception of University Support & .522 & .314 & .410 & .358 & .459 & .420 & .320 & .761 \\
\hline
\end{tabular}

We also examined the weights significance and collinearity issue for the formative indicators. Table 5 shows that all indicators weights are significant and there is no multicollinearity bias (Hair, Ringle, \& Sarstedt, 2013) as all VIFs are below the 5.00 threshold (Hair et al., 2014). Hence we assessed the structural model.

Table 5: Formative indicators weights, significance and test of multicollinearity

\begin{tabular}{lcccccc} 
Construct & Indicators & Weights & T Stat. & P Value & Tolerance & VIF \\
\hline Entrepreneurial Passion for Inventing & IPF-I & .840 & 89.845 & $.000^{* * *}$ & .586 & 1.706 \\
& IC-I & .235 & 31.478 & $.000^{\star * *}$ & .618 & 1.618 \\
Entrepreneurial Passion for Founding & IPF-F & .774 & 74.550 & $.000^{\star * *}$ & .481 & 2.078 \\
& IC-F & .314 & 36.349 & $.000^{* *}$ & .479 & 2.088 \\
\hline
\end{tabular}

***: $P<0.001$ 


\subsection{Structural model}

To examine the model's structural relationships we considered the path coefficients and their significance, and the $\mathrm{R}^{2}$ value (Hair et al., 2014). To establish the significance of the path coefficients we ran bootstrapping in PLS using 5000 subsamples (Hair et al., 2014). Table 6 shows the results of the hypotheses test, their coefficients, $t$ values and the $p$ values. Our analysis shows that all the hypotheses of the study were accepted.

Table 6: Path analysis and hypothesis testing (First Model)

\begin{tabular}{|c|c|c|c|c|c|c|}
\hline \multicolumn{2}{|c|}{ Hypotheses Hypotheses Path } & \multirow{2}{*}{$\frac{\text { Path Coefficient }}{.301}$} & \multirow{2}{*}{$\frac{\text { Standard Error }}{.052}$} & \multirow{2}{*}{$\frac{\text { T Value }}{5.784}$} & \multirow{2}{*}{$\frac{\text { P Value }}{.000^{\star \star \star}}$} & \multirow{2}{*}{$\begin{array}{l}\text { Decision } \\
\text { Supported }\end{array}$} \\
\hline$\overline{\mathrm{H} 1}$ & $\begin{array}{l}\text { Entrepreneurial Passion for Founding -> } \\
\text { Entrepreneurial Intention }\end{array}$ & & & & & \\
\hline $\mathrm{H} 2$ & $\begin{array}{l}\text { Entrepreneurial Passion for Inventing -> } \\
\text { Entrepreneurial Intention }\end{array}$ & .210 & .053 & 3.971 & $.000 * \star *$ & Supported \\
\hline H3 & $\begin{array}{l}\text { Perceive Creativity Disposition -> } \\
\text { Entrepreneurial Intention }\end{array}$ & .100 & .042 & 2.392 & $.009 * *$ & Supported \\
\hline $\mathrm{H} 4$ & $\begin{array}{l}\text { Perceive Effective Entrepreneurship Education - } \\
>\text { Entrepreneurial Intention }\end{array}$ & -.123 & .041 & 3.004 & .001 & Not Supported \\
\hline H5 & $\begin{array}{l}\text { Perception of University Support -> } \\
\text { Entrepreneurial Intention }\end{array}$ & .305 & .041 & 7.491 & $.000 * \star *$ & Supported \\
\hline
\end{tabular}

Hypotheses 1 predict a positive relationship between EPF and El, hence supported at $p<.001$. The relationship between $\mathrm{EPI}$ and EI (H2) was also accepted ( $p<.001)$. Hypothesis 3 predicts a positive relationship between PCD and El and accepted at $p<.01$. The positive relationship between PEEE and El (H4) was not accepted as the path coefficient is negative ( $B=-.123$ ). The last hypothesis (H5), showing the relationship between PUS and El (H5) was also accepted $(\mathrm{p}<.001)$. We also examined the $\mathrm{R}^{2}$ value of the endogenous construct (Entrepreneurial Intention). The $\mathrm{R}^{2}$ is classified as .25 (weak), .50 (moderate) and .75 (substantial) (Hair et al., 2010). Based on our $\mathrm{R}^{2}$ of .45 (see figure 1) we assumed close to moderate. We therefore, consider the results meaningful for interpretation purposes.

\section{Discussion}

Our findings show that the proposed positive relationship between perception of University support, perceived creativity disposition, entrepreneurial passion for inventing, entrepreneurial passion for founding and entrepreneurial intention were supported. These suggest that these variables will influence students to engage in entrepreneurial behaviour. Exception is the proposed positive relationship between perceived effective entrepreneurship education and entrepreneurial intention, which unexpectedly shows a significant but negative relationship and therefore was not supported. This suggests that the students' perception of effectiveness of the entrepreneurship education discourage them from wanting to engage in entrepreneurial activities after graduation.

This realization should be of a serious concern for the relevant agencies of the Nigerian government, as the introduction of compulsory entrepreneurship education to all higher institutions in Nigeria by the government is aimed at reducing graduate employability problem, by encouraging self-employment. We believe that the probable explanation is that this course is treated as a normal course that fulfills graduation process, so students do not see entrepreneurship education as intended to build their interest and push them to be self-employed towards becoming successful entrepreneurs and employers of labour.

To realize the government dream, the relevant stakeholders including the agencies and universities must support and monitor this programme. For example, by introducing practical aspect of entrepreneurship education and other strategies like running prototype companies in campuses by students could make the course more effective. This is confirmed by our finding of the significant positive relationship between the students' perception of University support and entrepreneurial intention, suggesting their perception of University support towards building their interest in entrepreneurship behaviour to be strong. We therefore provide empirical evidence of the positive influence of certain variables on entrepreneurial intention and subsequently entrepreneurship behaviour. 


\section{References}

Acs, Z. J., \& Audretsch, D. B. (2005). Entrepreneurship and innovation. Discussion Papers on Entrepreneurship, Growth and Public Policy, 2105.

Ajzen, I. (1991). The theory of planned behavior. Organizational behavior and human decision processes, 50, 179-211.

Albornoz, C., \& Rocco, T. S. (2013). Revisiting entrepreneurship education literature: Implications for learning and teaching entrepreneurship.

Arendt, S., \& Brettel, M. (2010). Understanding the influence of corporate social responsibility on corporate identity, image, and firm performance. Management Decision, 48, 1469-1492.

Ariff, A. H. M., Bidin, Z., Sharif, Z., \& Ahmad, A. (2010). Predicting entrepreneurship intention among Malay University Accounting students in Malaysia. UNIFAR e-journal, 6(1).

Autio, E., Keeley, R. H., Klofsten, M., \& Ulfstedt, T. (1997). Entrepreneurial intent among students: testing an intent model in Asia, Scandinavia and USA.

Bakotić, D., \& Kružić, D. (2010). Students' perceptions and intentions towards entrepreneurship: The empirical findings from Croatia. izlazi u samo elektroničkom izdanju: $N E$.

Baron, R. A. (2004). The cognitive perspective: A valuable tool for answering entrepreneurship's basic "why" questions. Journal of Business Venturing, 19, 221-239. doi: http://dx.doi.org/10.1016/S0883-9026(03)00008-9

Baron, R. A. (2008). The role of affect in the entrepreneurial process. Academy of management Review, 33, 328-340.

Batey, M., \& Furnham, A. (2008). The relationship between measures of creativity and schizotypy. Personality and Individual Differences, 45, 816-821.

Baum, J. R., \& Locke, E. A. (2004). The relationship of entrepreneurial traits, skill, and motivation to subsequent venture growth. Journal of Applied Psychology, 89, 587-598. doi: 10.1037/0021-9010.89.4.587

Bird, B. (1988). Implementing entrepreneurial ideas: The case for intention. Academy of management Review, 13, $442-453$.

Bird, B. J. (1989). Entrepreneurial behavior. Scott, Foresman Glenview, Illinois.

Cardon, M. S., Gregoire, D. A., Stevens, C. E., \& Patel, P. C. (2013). Measuring entrepreneurial passion: Conceptual foundations and scale validation. Journal of Business Venturing, 28, 373-396. doi: 10.1016/j.jbusvent.2012.03.003

Cardon, M. S., Wincent, J., Singh, J., \& Drnovsek, M. (2009b). The nature and experience of entrepreneurial passion. Academy of management Review, 34, 511-532.

Cardon, M. S., Zietsma, C., Saparito, P., Matherne, B. P., \& Davis, C. (2005). A tale of passion: New insights into entrepreneurship from a parenthood metaphor. Journal of Business Venturing, 20(1), 23-45. doi: 10.1016/j.jbusvent.2004.01.002

Charney, A., Libecap, G. D., \& Center, K. E. (2000). The impact of entrepreneurship education: An evaluation of the Berger Entrepreneurship Program at the University of Arizona. The Karl Eller Center of The College of Business and Public Administration.

Chen, X.-P., Yao, X., \& Kotha, S. (2009). Entrepreneur passion and preparedness in business plan presentations: A persuasion analysis of venture capitalists' funding decisions. Academy of Management journal, 52, 199-214.

Darini, M., Pazhouhesh, H., \& Moshiri, F. (2011). Relationship between employee's innovation (creativity) and time management. Procedia Social and Behavioral Sciences, 25, 201-213. doi: 10.1016/j.sbspro.2011.10.541

Davidsson, P. (1995). Determinants of entrepreneurial intentions. Paper prepared for the RENT IX Workshop, Piacenza, Italy, Nov. 23-24.

De Clercq, D., Castañer, X., \& Belausteguigoitia, I. (2011). Entrepreneurial initiative selling within organizations: Towards a more comprehensive motivational framework. Journal of Management Studies, 48, 1269-1290.

Fitzsimmons, J. R., \& Douglas, E. J. (2011). Interaction between feasibility and desirability in the formation of entrepreneurial intentions. Journal of Business Venturing, 26, 431-440. doi: 10.1016/j.jbusvent.2010.01.001

Fornell, C., \& Larcker, D. F. (1998). Evaluating structural equation models with unobservable variables and measurement error. Journal of Marketing Research, 18(1), 39-50.

Franke, N., \& Lüthje, C. (2004). Entrepreneurial intentions of business students-a benchmarking study. International Journal of Innovation and Technology Management, 1, 269-288.

Hamidi, D. Y., Wennberg, K., \& Berglund, H. (2008). Creativity in entrepreneurship education. Journal of Small Business and Enterprise Development, 15, 304-320. doi: 10.1108/14626000810871691

Hair, J. F., Black, W. C., Babin, B. J., \& Anderson, R. E. (2010). Multivariate data Analysis (7th ed.). NJ: Prentice Hall.

Hair, J. F., Hult, G. T. M., Ringle, C. M., \& Sarstedt, M. (2014). A primer on partial least squares structural equation modeling (PLS-SEM). Thousand Oaks: Sage.

Hair, J. F., Ringle, C. M., \& Sarstedt, M. (2013). Partial least squares structural equation modeling: Rigorous applications, better results and higher acceptance. Long Range Planning, 46(1-2), 1-12.

Hair, J. F., Sarstedt, M., Ringle, C. M., \& Mena, J. A. (2012). An assessment of the use of partial least squares structural equation modeling in marketing research. Journal of the Academy of Marketing Science, 40(3), 414-433.

Henseler, J., Ringle, C.M., \& Sarstedt, M. (2012). Using partial least squares path modeling in international advertising research: basic concepts and recent issues. In: Okazaki, S. (Ed.), Handbook of Research in International Advertising. Edward Elgar Publishing, Cheltenham, pp. 252-276.

Hisrich, R. D. (1990). Entrepreneurship/intrapreneurship. American Psychologist, 45, 209.

Keat, O. Y., Selvarajah, C., \& Meyer, D. (2011). Inclination towards entrepreneurship among university students: An empirical study of Malaysian university students. International Journal of Business and Social Science, 2, 206-220.

Krueger Jr, N. F., Reilly, M. D., \& Carsrud, A. L. (2000). Competing models of entrepreneurial intentions. Journal of Business Venturing, 15, 411-432. 
Krueger, N. F. (2007). What lies beneath? The experiential essence of entrepreneurial thinking. Entrepreneurship Theory and Practice, 31, 123-138.

Krueger, N. F., \& Carsrud, A. L. (1993). Entrepreneurial intentions: Applying the theory of planned behaviour. Entrepreneurship \& Regional Development, 5, 315-330.

Lee, S. H., \& Wong, P. K. (2004). An exploratory study of technopreneurial intentions: A career anchor perspective. Journal of Business Venturing, 19(1), 7-28.

Lin, E., Lin, T. M., \& Lin, B.-W. (2010). New high-tech venturing as process of resource accumulation. Management Decision, 48, $1230-1246$.

Liñán, F., \& Chen, Y. W. (2009). Development and cross-cultural application of a specific instrument to measure entrepreneurial intentions. Entrepreneurship Theory and Practice, 33, 593-617.

Liñán, F., Rodriguez-Cohard, J. C., \& Rueda-Cantuche, J. M. (2005). Factors affecting entrepreneurial intention levels. Paper presented at the 45th Congress of the European Regional Science Association, Amsterdam.

Liñán, F., Urbano, D., \& Guerrero, M. (2011b). Regional variations in entrepreneurial cognitions: Start-up intentions of university students in Spain. Entrepreneurship \& Regional Development, 23, 187-215. doi: 10.1080/08985620903233929

Lüthje, C., \& Franke, N. (2003). The 'making'of an entrepreneur: testing a model of entrepreneurial intent among engineering students at MIT. R\&d Management, 33, 135-147.

Murnieks, C. Y., Mosakowski, E., \& Cardon, M. S. (2011). Pathways of fire: An empirical look at entrepreneurial passion. Frontiers of entrepreneurship research, 31(4), 2.

Nabi, G., \& Liñán, F. (2011). Graduate entrepreneurship in the developing world: Intentions, education and development. Education + Training, 53, 325-334. doi: 10.1108/00400911111147668

Packham, G., Jones, P., Miller, C., Pickernell, D., \& Thomas, B. (2010). Attitudes towards entrepreneurship education: A comparative analysis. Education+ Training, 52, 568-586.

Peterman, N. E., \& Kennedy, J. (2003). Enterprise education: Influencing students' perceptions of entrepreneurship. Entrepreneurship Theory and Practice, 28, 129-144.

Ringle, C., Sarstedt, M., \& Straub, D. (2012). A critical look at the use of PLS-SEM in $\quad$ the MIS quarterly. MIS Quarterly, 36, iii-xiv.

Ringle, C.M., Wende, S., Will, A. (2005). "SmartPLS 2.0." www.smartpls.de.

Robinson, P., \& Haynes, M. (1991). Entrepreneurship education in America's major universities. Entrepreneurship Theory and Practice, 15(3), 41-52.

Rodrigues, R., Dinis, A., Paço, A., \& Ferreira, J. (2008). The effect of an entrepreneurial training programme on the entrepreneurial intention of secondary students. Proceedings of RENT XXI-Research in Entrepreneurship and Small Business.

Rowley, J., Baregheh, A., \& Sambrook, S. (2011). Towards an innovation-type mapping tool. Management Decision, 49(1), 73-86.

Schiavone, A. (2011). L'histoire brisée. La Rome antique et l'Occident moderne (La storia spezzata. Roma antica e Occidente moderno), Paris, Belin, 2009 (édition originale en 1996, première édition en français en 2003), 384 pages, 8 euros. Par Jean-Guillaume Lanuque.

Schwarz, E. J., Wdowiak, M. A., Almer-Jarz, D. A., \& Breitenecker, R. J. (2009). The effects of attitudes and perceived environment conditions on students' entrepreneurial intent: An Austrian perspective. Education + Training, 51, 272-291. doi: 10.1108/00400910910964566

Segal, G., Borgia, D., \& Schoenfeld, J. (2005). The motivation to become an entrepreneur. International Journal of Entrepreneurial Behaviour \& Research, 11(1), 42-57.

Shane, S., \& Venkataraman, S. (2000). The promise of entrepreneurship as a field of research. Academy of management Review, 25, 217-226.

Shapero, A., \& Sokol, L. (1982). The social dimensions of entrepreneurship. Encyclopedia of entrepreneurship, 72-90.

Shaver, K., Williams, S., \& Scott, L. (1991). Personality or situation: Can entrepreneurs be created?

Souitaris, V., Zerbinati, S., \& Al-Laham, A. (2007). Do entrepreneurship programmes raise entrepreneurial intention of science and engineering students? The effect of learning, inspiration and resources. Journal of Business Venturing, 22, 566-591. doi: 10.1016/j.jbusvent.2006.05.002

Sundararajan, M., \& Peters, L. (2007). Role of emotions in the entrepreneur's opportunity recognition process. Paper presented at the annual meeting of the Academy of Management, Philadelphia.

Vallerand, R. J., Salvy, S.-J., Mageau, G. A., Elliot, A. J., Denis, P. L., Grouzet, F. M. E., \& Blanchard, C. (2007). On the role of passion in performance. Journal of Personality, 75, 505-534. doi: 10.1111/j.1467-6494.2007.00447.x

Wang, Y., \& Verzat, C. (2011). Generalist or specific studies for engineering entrepreneurs?: Comparison of French engineering students' trajectories in two different curricula. Journal of Small Business and Enterprise Development, 18, 366-383. doi: $10.1108 / 14626001111127124$

Ward, A. (2005). An integrated model of entrepreneurship and intrapreneurship. Retrieved January, 18, 2007.

Ward, T. B. (2004). Cognition, creativity, and entrepreneurship. Journal of Business Venturing, 19, 173-188.

Wilson, B. (2010). Using PLS to investigate interaction effects between higher order branding constructs. In: Vinzi, V.E., Chin, W.W., Henseler, J., Wang, H. (Eds.), Handbook of Partial Least Squares: Concepts, Methods and Applications in Marketing and Related Fields. Springer, Berlin, pp. 621e652.

Wilson, F., Kickul, J., \& Marlino, D. (2007). Gender, entrepreneurial self efficacy, and entrepreneurial career intentions: Implications for entrepreneurship education. Entrepreneurship Theory and Practice, 31, 387-406.

Zhou, J., \& George, J. M. (2001). When job dissatisfaction leads to creativity: Encouraging the expression of voice. Academy of Management journal, 44, 682-696. 